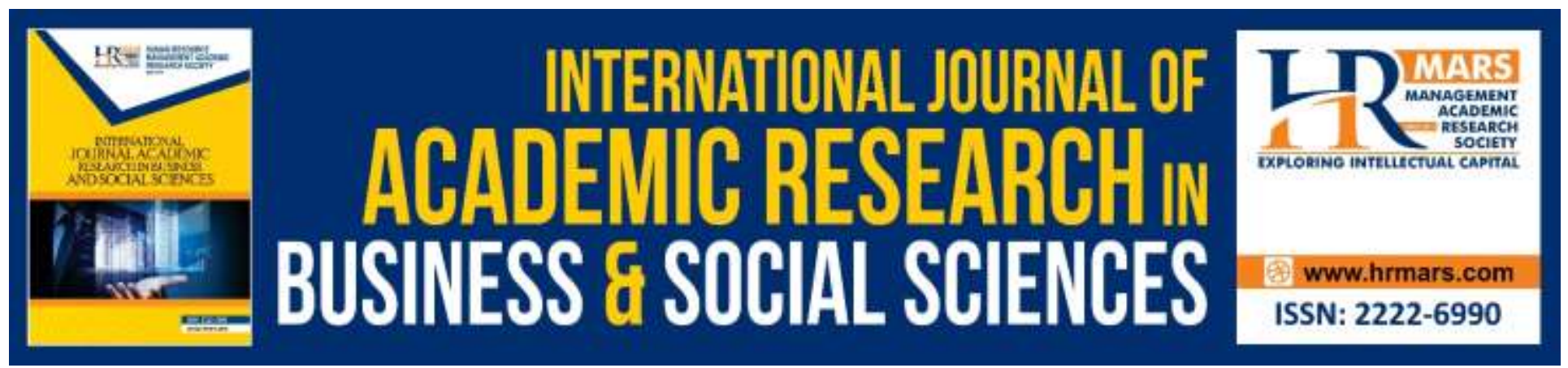

\title{
Generation Z for Job Employment: Characteristic and Expectation
}

\section{Ruhil Amani Said, Mas Anom Abdul Rashid, Mohd Azman Othman}

To Link this Article: http://dx.doi.org/10.6007/IJARBSS/v10-i3/7072

DOI:10.6007/IJARBSS/v10-i3/7072

Received: 07 February 2020, Revised: 20 February 2020, Accepted: 12 March 2020

Published Online: 30 March 2020

In-Text Citation: (Said et al., 2020)

To Cite this Article: Said, R. A., Rashid, M. A. A., \& Othman, M. A. (2020). Generation Z for Job Employment: Characteristic and Expectation. International Journal of Academic Research in Business and Social Sciences, 10(3), 570-575.

Copyright: (C) 2020 The Author(s)

Published by Human Resource Management Academic Research Society (www.hrmars.com)

This article is published under the Creative Commons Attribution (CC BY 4.0) license. Anyone may reproduce, distribute, translate and create derivative works of this article (for both commercial and non-commercial purposes), subject to full attribution to the original publication and authors. The full terms of this license may be seen at: http://creativecommons.org/licences/by/4.0/legalcode

$$
\text { Vol. 10, No. 3, 2020, Pg. } 570 \text { - } 575
$$

Full Terms \& Conditions of access and use can be found at http://hrmars.com/index.php/pages/detail/publication-ethics 


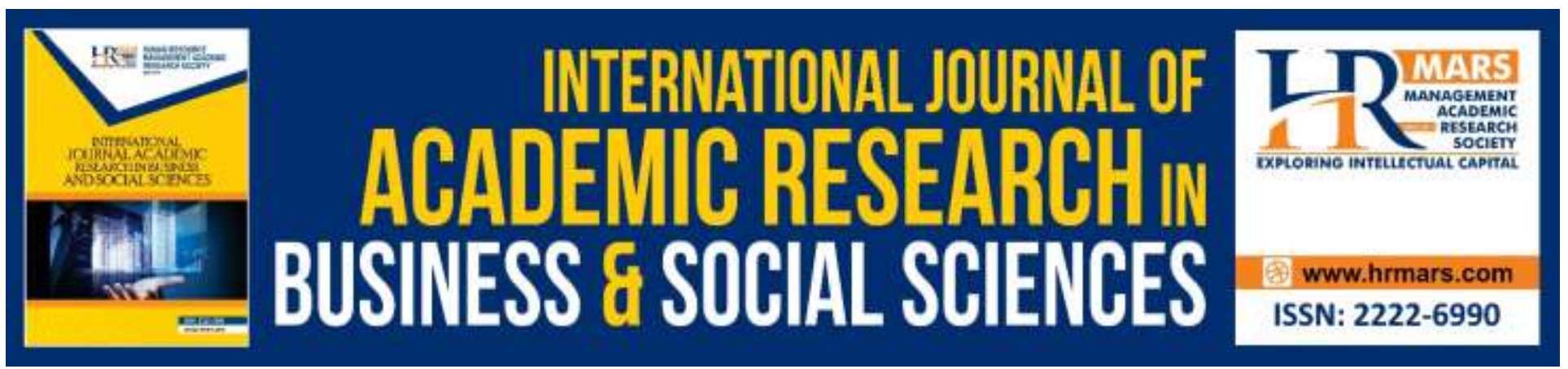

\title{
Generation Z for Job Employment: Characteristic and Expectation.
}

\author{
Ruhil Amani Said \\ Institute of Graduate Studies, College University Poly-Tech MARA Kuala Lumpur, Malaysia.
}

\author{
Mas Anom Abdul Rashid, Mohd Azman Othman \\ Senior Lecturer, Institute of Graduate Studies, College University Poly-Tech MARA Kuala Lumpur, \\ Malaysia.
}

\begin{abstract}
The aim of the study is to fill the gap about generation $Z$ and their expectation on the job surrounding. It is also hope to provide employers with information on the necessary training, working atmosphere, preferred communication and management style by the future employees thus, ensuring the appropriate preparation to embrace the new generation $Z$ as employees in organizations be it private or public sector. Since Malaysian do not have much literature on Gen Z, therefore, this study has to take the US literature on Gen Z statistic.
\end{abstract}

Keywords: Gen Z, Future Workforce, Characteristic, Expectation and Human Resource Management.

\section{Introduction}

Generations are defined by Cambridge English Dictionary, the experience and events that all the people of about the same age within a society or within a particular family. Other, definition is that a generation is "Identifiable group sharing birth years, age, place and significant life events at critical phases of development" (Tolbize, 2008). While, (Bolat, Tamer \& Seymen, Oya \& Pearl Bolat, Oya \& Kinter, Oguzhan \& solid, Yahya, 2018), Generation is described as an recognizable group sharing birth years, age, place, and significant life events at critical developmental phases, split into five to seven years: first wave, key group, and last wave.

History has shown that a fresh generation entering the workforce often leads to comparisons with those who arrived before, along with a great deal of anticipation and predictions that may be precise, especially about how the generation might disrupt the workforce. As an example, Millennial were projected to introduce new forms of communication and prioritize the social responsibility of their employers (Ferri-Reed, 2016), while demonstrating less loyalty to the organizations they serve (Deloitte, 2016). 
INTERNATIONAL JOURNAL OF ACADEMIC RESEARCH IN BUSINESS AND SOCIAL SCIENCES Vol. 10, No. 3, March, 2020, E-ISSN: 2222-6990 @ 2020 HRMARS

\section{Characteristic of Generation Z}

Previous researchers have shown that Gen $Z$ is different from the Millennial as reported by Ernst \& Young (2016) in a survey of 3,200 Gen Z in Brazil, China, Germany, India, Japan, Mexico, UK and US. It has been identified that Gen $Z$ value "Employers who provide equal pay and promotion possibilities, possibilities for professional learning and advancement. They also revealed that Gen $Z$ prefers employers who treat individuals with regard, ethical behavior, fair compensation and promotion, open and transparent communication and wise company decision-making. Being independent, self-confident and autonomous are also some of the key characteristics of generation $Z$. They are not relying as much on their parents as they were on prior adolescent generations. The reason for this is that the internet and techniques enable gen $\mathrm{Z}$ to begin earning cash much sooner than their parents.

However, $11 \%$ of global respondents, which includes $18 \%$ from US indicated that their caretakers' work experience had a "very or somewhat negative" impact on the level of trust they would place in future employers. They also include that poor quality of raises, dislike of job, or dislike or distrust of boss, colleagues or top-level executives among those negative indicators.

In a second survey of 1,000 adults and 400 teens which examines their mindset behind changing consumer behavior between millennial and post-millennial Gen Z (Merriman \& Velario, 2016) on retail consumption it was also found that Gen $Z$ desire more personalized micro-experience and feel like "anything is possible" (Merriman, 2016). They are also susceptible to buying online products because of ease, effectiveness, convenience, better choice and reduced cost (Merriman \& Valerio, 2016). These findings can be applied to consumption of educational resources as well.

For a better understanding of Generation $Z$ and its digitization, it should be noted that "they were born in the 1990s and raised in the 2000s during the most profound changes of the century in a world of web, internet, smartphones, laptops, free networks and digital media." (Singh, Dangmei, 2016, p. 2). "This generation is about to spend its youth and adults in an age of financial and social renewal" (Sidorcuka, Chesnovicka, 2017, p. 809).

\section{Generation Z Expectations}

The Wall Street Journal (2018) reported that a fresh generation of employees who were born after 1995 enter the workforce with their own skills, needs and expectations. These employees are employees of the Gen Z. While Gen Z's digital natives may have an unprecedented technological ability, many studies revealed that Gen Z participants voiced fears that dependence on technology might have impacted other abilities such as communication and problem-solving. (Friedman, 2018).

These abilities can lead to effective relationship construction and drive the accumulation of tacit knowledge, i.e. process information, customer data, or culture that is passed on through years of personal cooperation and communication within organizations. This sort of expertise is essential for the long-term achievement and growth of management of organizations that could decrease if practitioners lack the abilities to obtain and share it. Many elements of their general talent approach can be evaluated by organizations, including:

\section{Talent Acquisition}

The evolving nature of the job has pushed businesses to reconsider the abilities they seek in hiring personnel at the entrance level. For example, an organization that has earlier sought applicants with 
particular technical expertise may decide to prioritize applicants who show mental agility to move between fields and across positions within the organization. There may also be a greater focus on "STEMpathic" professionals, who can have technical knowledge and cognitive skills (Engelbert \& Hagel, 2017).

Organizations can also reconsider techniques of recruitment. While traditional reviews and behavioral interviews may continue to be helpful for certain positions, recruitment for employment that prioritize cognitive skills may be more efficient when integrating experiential techniques. Competitions, for example, are a helpful way of testing creativity, communication skills and cooperative engagement, and can enable recruiters to observe interpersonal skills in action.

\section{Deployment and Assignment}

According to Deloitte Wall Street Journal Report (2018), many experts are looking for a multidisciplinary and international focus on their job, hoping that this will generate possibilities for mobility and a wealth of experiences.

Organizations can assist satisfy this need through the internal and external creation of structured rotation programs. For example, working with an enterprise partner ecosystem to offer possibilities for joint rotation and positioning. In addition to these programs, businesses can provide staff with varied experiences through techniques such as crowd-sourcing, enabling experts to pick up tiny side projects and learn fresh topics without committing to a shift in role. Organizations can also use data analytics to assist determine the capacities, experiences and behaviors associated with high results in particular positions and at different rates.

\section{Culture}

Deloitte also claims that, in relation to rethinking talent approach and procedures, company officials can consider how to incorporate fresh staff into the current culture of the organization and how to improve that culture. Many experts value flexibility and prioritize well-being in relation to desiring mobility and growth possibilities. Benefits such as paid time off, family leave, and wellness programs may be more relevant to staff when placed as part of the broader engagement and culture openly endorsed by politicians. Many experts expect such programs instead of seeing them as a benefit. Companies can also evaluate how transparent their cultures are. Many experts can expect open business strategy discussions and choices, including bad news about product mistakes, layoffs or competitive threats. Figure 1 Show the shift to future workers for generation $\mathrm{Z}$.

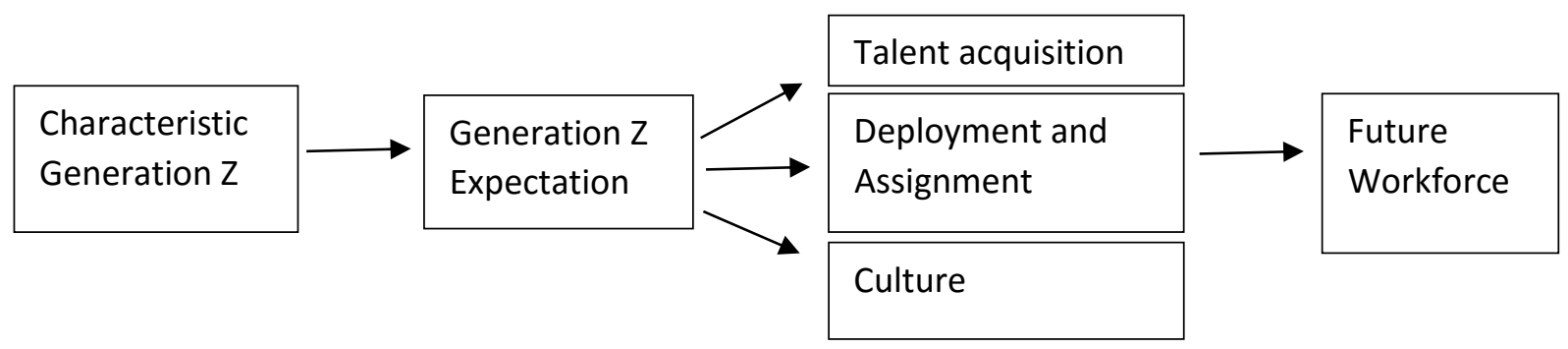

Figure 1. Diagrams the shifted Generation Z toward future workforce 
INTERNATIONAL JOURNAL OF ACADEMIC RESEARCH IN BUSINESS AND SOCIAL SCIENCES Vol. 10, No. 3, March, 2020, E-ISSN: 2222-6990 @ 2020 HRMARS

\section{Conclusion}

In the industry we have multigenerational workforce. Expert has loosely divided the five generations into the 'builders' (or matures/veterans), 'baby boomers' and the respective generations ' $X$ ', ' $Y$ ' and ' $Z$ '. Debatable identity is strongly formed by generation than by either gender or religion. Currently we have three generations involve in the workforce: the baby boomers, generation $\mathrm{X}$ and generation Y. Each generation is labelled with their specific character. All generations bring their own unique character in the industry. The baby boomers have traditionally worked longer hours and put their effort all out toward their job. This has made them the workhorses of the profession. Generation $X$ and $Y$ are defined by a different grasp on technology, mobility and an ideology that seeks a balance in life. Generation Z (born 1991-2006) is likely to follow in aunty Y's footsteps in terms of behavior. If the current models of education continue, we can expect our first gen $Z$ to begin work as an intern in 2017 (Mitchell, DA, 2008). Just two years back, it is too early to make conclusion on who is Gen Z. It is important to investigate their characteristic, expectation, attitude and preference to sustain the industry or organization relevancy in modern world what they call "Gig Economy".

Stillman and Stillman (2016) and Ferri-Reed (2016) suggest that employers have to understand the diversify generations, i.e. Gen $X, Y$ and $Z$, as their preference and matters of importance are diverse, therefore, to ease planning and development model and the success of organizations, it is suggested that employers need to understand Gen $Z$ as they are entering the workforce today and more will be pouring in soon. With the different characters, experience and behavior, different generation's expectation varies. As Gen Z are also known as the "privilege" generation, therefore, there is a need to explore this generation to see their needs and expectation to see how it will predict the future of the workforce.

\section{Corresponding Author}

Mas Anom Abdul Rashid, Senior Lecturer College University Poly-Tech MARA Kuala Lumpur, Malaysia

Email: masanom@kuptm.edu.my,

\section{References}

Zopiatis, A., Krambia-Kapardis, M., \& Varnavas, A. (2012). Y-ers, X-ers and Boomers: Investigating the multigenerational (mis) perceptions in the hospitality workplace. Tourism and Hospitality Research, 12(2), 101-121.

Bolat, O. I., Bolat, T., Seymen, O., \& Yüksel, M. (2017). The Relationship Between Power Distance and Paternalist Leadership: An Assessment from The Perspective Generation. Balikesir University Journal of Social Sciences Institute, 20(38).

Donovan, S. A., Bradley, D. H., \& Shimabukuro. (2016). What does the gig economy mean for workers? (CRS Report R44365). Washington, DC: Congressional Research Service.

Deloitte. (2016). The 2016 Deloite Millennial Survey: Winning over the next generation of leaders. Deloitte Touche Tohmatsu Limited. Retrieve from https://www2.deloitte.com/content/dam/Deloitte/global/Documents/About-Deloitte/gxmillenial-survey-2016-exec-summary.pdf [Google Scholar]

Engelbert, C., \& Hagel, J. (2017). Fulfilling the promise of Al means rethinking the nature of work itself. Harvard Business Review, December 18. 
INTERNATIONAL JOURNAL OF ACADEMIC RESEARCH IN BUSINESS AND SOCIAL SCIENCES

Vol. 10, No. 3, March, 2020, E-ISSN: 2222-6990 @ 2020 HRMARS

Ernst \&Young. (2016). Global generations, 26. Retrived June 11,2018 from

http://www.ey.com/us/en/about-us/our-people-and-culture/ey-work-life-challengesacrossgenerations-global-study.

Ferri-Reed, J. (2014). Are millennial employees changing how managers manage? The Journal for Quality and Participation, 37(2), 15.

Friedman, M. (2018). Theory of the consumption function. Princeton university press.

Jorgenson, B. (2003). Baby boomers, generation X \& generation Y: Policy implications for defense forces in the modern era. Foresight, 5, 41-49.

Rothman, D. (2016). A Tsunami of learners called Generation Z. URL: http://www. mdle. net/JoumaFA_Tsunami_of_Learners_Called_Generation_Z.pdf.

Singh, A. P., Dangmei, J. (2016). Understanding the generation Z: the future workforce. South-Asian Journal of Multidisciplinary Studies, 3(3), 1-5.

Sidorcuka, I., Chesnovicka, A. (2017). Methods of attraction and retention of generation Z staff. CBU International Conference Proceedings, 5, 807-815. DOI: 10.12955/cbup.v5.1030.

Tolbize, A. (2008). Generational differences in the workplace. Research and training center on community living, 5(2), 1-21.

Yang. S. M., \& Guy, M. E. (2006). Gen Xers versus boomers: Work motivators and management implications. Public Performance \& Management Review, 29, 267-284.

Zemke, R., Raines, C., \& Filipczak, B. (1999). Generations at work: Managing the clash of Veterans, Boomers, Xers, and Nexters in your workplace. Amacom. 